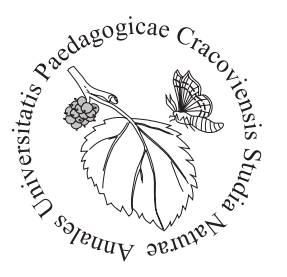

Ewa Sosnówka-Czajka*, Iwona Skomorucha Department of Poultry Breeding, National Research Institute of Animal Production, Kraków, Poland, *ewa.sosnowka@izoo.krakow.pl

\title{
Selected blood parameters in organically raised hens fed with a purple coneflower supplemented diet ${ }^{* *}$
}

${ }^{*}$ Carried out based on Ministry of Agriculture and Rural Development decision no. HOR.re.027.5.2017

\section{Introduction}

Organic farming requires continuous care for a high health status of birds to make poultry production profitable and to obtain quality products, which is of direct interest to consumers. Impaired immune function leads to deterioration in productivity, e.g., poorer laying performance, lower hatchability, or increased mortality (Yunis et al., 2000; Sivaraman et al., 2005). On the other hand, by stimulating the immune system through modified nutrition, it is possible to reduce the negative effects of compromised immunity in poultry (Truchliński et al., 2006; Salim et al., 2018). Environmental stress associated with the used rearing system may, in general, interfere with antibody production and cellular immune response, making poultry more vulnerable to vital infections (Bartlett, Smith, 2003).

At present, organic farmers are focused on increasing their use of herbs and herbal mixtures, which have positive effects on the animals' metabolism, health, productivity, feed conversion, and reproduction. A large number of biologically active therapeutic substances are found in purple coneflower, including polysaccharides, glycoproteins, and alkaloids (Dalby-Brown et al., 2005). Many of these substances are used to improve the body's immune potential and to enhance macrophage activity (Goel et al., 2002). Allen (2003) reported that purple coneflower extract can be used to increase resistance to coccidiosis in birds kept on litter. According to Najafzadeh et al. (2011), purple coneflower can be an effective means to prevent avian influenza in birds.

Therefore, the aim of this study was to determine the effect of a dietary addition of dried purple coneflower (Echinacea purpurea (L.) Moench) on selected blood parameters of chicks and hens of the native 'Greenleg Partridge' breed (Z-11), maintained according to organic farming principles. 
Animals and experimental design

The experiment was carried out on 252 'Greenleg Partridge' hens (R-11) aged 20 weeks (wks) with 126 birds in each group with 6 subgroups per group. In each experimental subgroup, there was 1 rooster to 7 layers. Hens were maintained on a certified poultry farm according to organic farming principles. Birds were divided into two groups according to diet: organic layer diet (group 1), and the same diet supplemented with certified purple coneflower (Echinacea purpurea (L.) Moench) from 20 wks of age at $10 \mathrm{~g} /$ $\mathrm{kg}$ feed (group 2). Layers were fed the certified layer diet (17\% protein and 11.1 MJ ME/ $\mathrm{kg}$ diet) following organic farming principles. The diets contained organic components such as maize, wheat, soybean expeller, sunflower cake, triticale, dehulled heat-treated lupin, peas, broad bean, soybean, maize gruel, dried lucerne, soybean oil, molasses, and monocalcium phosphate. Throughout the study, hens were fed ad libitum (optimal) and had constant access to water. Hens were kept on litter (6 birds $/ \mathrm{m}^{2}$ of floor area) and were allowed access to grassy yards $\left(4 \mathrm{~m}^{2} /\right.$ bird). The yards were equipped with roofs and drinkers. The microclimate conditions and the light programme were adjusted to the ages of the birds in keeping with pullet rearing and layer management standards. At 34 weeks of rearing, eggs were collected for experimental incubations (100 eggs from each group). Eggs were incubated for 21 days under standard conditions.

Sample collection and laboratory analyses Blood was collected from laying hens (from 15 birds per group - $2.5 \mathrm{ml}$ from each hen) at 34 wks and from newly hatched chicks at one day of age (from 15 birds per group - $1 \mathrm{ml}$ from each chick) to determine selected blood parameters. The circulating immunoglobulin complex was determined by the procedure of Lowry (Lowry et al., 1951) modified by Ślebodziński et al. (1982), and IgG was analysed by quantitation tests (Chicken IgG ELISA Kit, Alpha Diagnostic Intl., Inc.). The results were read using a Tecan Spectra Classic reader based on KCJunior software (Bio-Tek Instruments, Inc.). Blood for haematocrit determinations was centrifuged in haematocrit capillaries with an MPW-52 centrifuge, and the result was read from a reader placed on the centrifuge rotor. Blood smears were stained with a May-Grünwald-Giemsa (MGG) protocol for calculation H:L. The number of red and white blood cells was counted in a Bürker chamber under a Nikon YS 100 microscope.

Statistical analysis

The results were statistically analysed by one-way analysis of variance and estimated with Duncan's test. The statistical calculations were made with Statistica ver. 12 software. 
Appendix 1 - figure 1 shows the levels of the circulating immunoglobulin complex in 35-week-old organic 'Greenleg Partridge' hens and in day-old chicks derived from these hens. There was only a tendency for higher immunoglobulin complex in birds fed the purple coneflower diet. Similar relationships were observed for IgG, and the lack of statistically significant differences results from a large scatter of data (Appendix 1 - Fig. 2). Z-11 hens fed the purple coneflower diet and chicks originating from them were characterised by the lowest H:L ratio at $\mathrm{p} \leq 0.05$ (Appendix $1-$ Fig. 3). No significant differences were observed between the experimental groups of Z-11 hens and chicks in the level of leukocytes (Appendix 1 - Fig. 4), erythrocytes (Appendix 1 - Fig. 5) and haematocrit (Appendix 1 - Fig. 6).

\section{Discussion}

The body's immunity depends on the maintenance of immune homeostasis which is associated with systemic homeostasis. The efficiency of the immune system is often determined from the level of immunoglobulins (Sivaraman et al., 2005). According to Wang et al. (2000), total Ig level may be indicative of the potential efficiency of the humoral system, whereas the IgG level does not always reflect the actual activity of the immune system. Singh et al. (2006) concluded that circulatory immune complexes in broiler chickens average $2.46 \mathrm{~g} / \mathrm{dl}$ and increase to $2.99 \mathrm{~g} / \mathrm{dl}$ after stimulating the immune system with dietary vitamin E and selenium. In our study, the circulatory immune complexes tended to increase by about $15 \%$ in the blood serum of 'Greenleg Partridge' hens fed a purple coneflower supplemented diet compared to the hens fed a standard organic diet.

One of the indicators of chick quality is the body's immunity, which allows the chicks to counteract the development of pathogens, thus having a positive effect on their survival during rearing (Kogut, Klasing, 2009; Korver, 2012). In birds, maternal antibodies are transferred from layer's serum to egg yolk and later to the yolk sac and blood circulatory system, which provides the embryos and newly hatched chicks with passive immunity (West et al., 2004; Bencina et al., 2005). Because the level of immunity in laying hens determines the immunity of the chicks, in our study, we found a similar relationship for the chicks from Z-11 hens supplemented with purple coneflower as in adult birds, namely, a tendency for the circulating immune complexes to increase by $9 \%$. Our study showed very large individual differences in the level of circulating immune complexes; therefore, they were not significant, despite high differences between the groups. 
Serum IgG level in chickens reflects the body's humoral immunity status (Juul-Madsen, Sørensen, 2004). In our study, we found the level of immunoglobulins to vary widely between individual birds. Therefore, although between-group differences in IgG concentration were high and reached $23 \%$, they were not statistically significant. Similar correlations were also observed by Wang et al. (2000). Carlander et al. (2003) showed high individual differences in IgY levels between egg yolks. According to Najafzadeh et al. (2011), purple coneflower can be effective in improving poultry immunity. Yamada et al. (2011) found purple coneflower extract to increase IgA, IgG, and IgM levels. In our study, we did not find a conclusive effect of adding purple coneflower to the feed of 'Greenleg Partridge' hens kept in accordance with the rules of organic farming. Likewise, Gurbuz et al. (2010) reported no unequivocal effect of purple coneflower extract on the level of specific antibodies in 60-day-old HyLine pullets. In contrast, Chaves et al. (2007) and Ma et al. (2009) showed the number of specific antibodies to increase following purple coneflower supplementation.

Immune system efficiency is determined, among others, from the level of lymphocytes (Yurong et al., 2005). According to Wang et al. (2000), lymphocytes play a very significant role in the body's immune response, and a change in the proportion of lymphocyte subclasses alters the immune function. Yamada et al. (2011) reported purple coneflower extract to increase the level of lymphocytes. Jurkstiene et al. (2004) found that purple coneflower supplement increased the leukocyte and lymphocyte counts. According to Bany et al. (2003), purple coneflower extract influences the level of granulocytes and lymphocytes. Our study showed the effect of supplemental purple coneflower on the level of blood heterophils and lymphocytes in Z-11 hens. One of the parameters indicative of avian immunity is the heterophil to lymphocyte ratio (H:L). The purple coneflower supplement used in our study reduced the H:L ratio in layers, which may suggest that they were less stressed, more resistant, and showed better welfare compared to control hens. Similarly, the H:L ratio was lower in chicks hatched from eggs of hens receiving purple coneflower diets.

During the production process, poultry is constantly exposed to stress factors, including those related to the rearing system. Hangalapura et al. (2004a,b) hold that the cellular immune response becomes activated under chronic stress. Stress in laying hens decreased the number of white blood cells (Mashaly et al., 2004), but this can be counteracted through dietary modification, e.g., the addition of herbal immunostimulants. Goel et al. (2002) concluded that biologically active substances found in purple coneflower can be used to improve the body's immune potential and to increase macrophage activity. However, our study showed no effect of dietary purple coneflower on selected blood count parameters of organically raised 'Greenleg Partridge' hens.

In summary, the organically raised 'Greenleg Partridge' hens and chicks responded to the purple coneflower supplement by changes in blood picture, which are impor- 
tant indicators of avian health and condition. As in Z-11 chicks, purple coneflower supplemented to the layer diet reduced the $\mathrm{H}: \mathrm{L}$ ratio and induced a tendency for a higher level of the circulating immunoglobulin complex and IgG in blood, which shows their better living comfort and higher immunity. High individual variation occurred for the circulating immunoglobulin complex and IgG in the organically raised 'Greenleg Partridge' hens.

\section{References}

Allen, P.C. (2003). Dietary supplementation with Echinacea and development of immunity to challenge infection with coccidia. Parasitology Research, 91(1), 74-78. DOI: 10.1007/s00436-003-0938-y

Bany, J., Siwicki, A.K., Zdanowska, D., Sokolnicka, I., Skopińska-Rózewska, E., Kowalczyk, M. (2003). Echinacea purpurea stimulates cellular immunity and anti-bacterial defence independently of the strain of mice. Polish Journal of Veterinary Sciences, 6(3 Suppl), 3-5.

Bartlett, J.R., Smith, M.O. (2003). Effects of different levels of zinc on the performance and immunocompetence of broilers under heat stress. Poultry Science, 82, 1580-1588. DOI: 10.1093/ps/82.10.1580

Bencina, D., Narat, M., Bidovec, A., Zorman-Rojs, O. (2005). Transfer of maternal immunoglobulins and antibodies to Mycoplasma gallisepticum and Mycoplasma synoviae to the allantoic and amniotic fluid of chicken embryos. Avian Pathology, 34(6), 463-472. DOI: 10.1080/03079450500368011

Carlander, D., Wilhelmson, M., Larsson, A. (2003). Immunoglobulin Y levels in egg yolk from three chicken genotypes. Food and Agricultural Immunology, 15, 35-40. DOI: 10.1080/0954010031000138087

Chaves, F., Chacon, M., Badilla, B., Arevalo, C. (2007). Effect of Echinacea purpurea (Asteraceae) aqueous extract on antibody response to Bothrops asper venom and immune cell response. Revista de Biologia Tropical, 55, 113-119. DOI: 10.15517/rbt.v55i1.6061

Dalby-Brown, L., Barsett, H., landbo, A.K., Meyer, A.S., Molgaard, P. (2005). Synergistic antioxidative effects of alkamides, caffeic acid derivatives, and polysaccharide fractions from Echinacea purpurea on in vitro oxidation of human low-density lipoproteins. Journal of Agricultural and Food Chemistry, 53, 9413-9423. DOI: 10.1021/jf0502395

Goel, V., Chang, C., Slama, J.V., Barton, R., Bauer, R., Gahler, R., Basu, T.K. (2002). Alkylimides of Echinacea purpurea stimulate alveolar macrophage function in normal rats. International Immunopharmacoly, 2-3, 381-387. DOI: 10.1016/S1567-5769(01)00163-1

Gurbuz, E., Balevi T., Kurtoglu, V., Coskun, B., Oznurlu, Y., Kan, Y., Kartal, M. (2010). Effects of Echinacea extract on performance, antibody titres, and intestinal histology of layer chicks. British Poultry Science, 51(6), 805-810. DOI: 10.1080/00071668.2010.528753

Hangalapura, B.N., Nieuwland, M.G., de Vries Reilingh, G., van den Brand, H., Kemp, B., Parmentier, H.K. (2004b). Durations of cold stress modulates overall immunity of chicken lines divergently selected for antibody responses. Poultry Science, 83, 765-775. DOI: 10.1093/ps/83.5.765

Hangalapura, B.N., Nieuwland, M.G.B., Busse, J., Kemp, B., Parmentier, H.K. (2004a). Effect of duration of cold stress on plasma adrenal and thyroid hormone levels and immune responses in chicken lines divergently selected for antibody responses. Poultry Science, 83, 1644-1649. DOI: 10.1093/ ps/83.10.1644

Jurkstiene, V., Kondrotas, A.J., Kevelaitis, E. (2004). Compensatory reactions of immune system and action of purple coneflower (Echinacea purpurea (L.) Moench) preparations. Medicina (Kaunas), 40(7), 657-662. 
Juul-Madsen, H.R., Sørensen, P. (2004). Influence of early or late start of first feeding on growth and immune phenotype of broilers. British Poultry Science, 45(2), 210-222. DOI: 10.1080/00071660410001715812

Kogut, M.H., Klasing, K. (2009). An immunnologist's perspective on nutrition, immunity, and infectious diseases: Introduction and overview. Journal of Applied Poultry Research, 18, 103-110. DOI: 10.3382/ japr.2008-00080

Korver, D., (2012). Implications of changing immune function through nutrition in poultry. Animal Feed Science and Technology, 173, 54-64. DOI: 10.1016/j.anifeedsci.2011.12.019

Lowry, O.H., Rosebrough, J.M., Farr, A.L., Randall, R.J. (1951). Protein measurement with the Folin phenol reagent. Journal of Biological Chemistry, 193, 265-269.

Ma, A., Shi, W., Niu, X., Wang, M., Zhong, X. (2009). Effects of Echinacea purpurea extract on the immunological response to infectious bursal disease vaccine in broilers. Frontiers of Agriculture in China, 3 , 452-456. DOI: 10.1007/s11703-009-0039-5

Mashaly, M.M., Hendricks, G.L., Kalama, M.A., Gehad, A.E., Abbas, A.O., Patterson, P.H. (2004). Effect of heat stress on production parameters and immune responses of commercial laying hens. Poultry Science, 83, 889-894. DOI: 10.1093/ps/83.6.889

Najafzadeh, H., Ghorbanpour, M., Mayahi, M., Gavzan, H. (2011). Effect of Echinacea purpurea on antibody production against fowl influenza vaccine. Journal of Applied Anim. Research, 39(2), 139-141. DOI: 10.1080/09712119.2011.565555

Puthpongsiriporn, U., Scheideler, S.E. (2005). Effects of dietary ratio of linoleic to linolenic acid on performance, antibody production, and in vitro lymphocyte proliferation in two strains of leghorn pullet chicks. Poultry Science, 84(6), 846-857. DOI: $10.1093 / \mathrm{ps} / 84.6 .846$

Salim, H.M., Kang, H.K., Akter, N., Kim, D.W., Kim, J.H., Kim, M.J., Na, J.C., Jong, H.B., Choi, H.C., Suh, O.S., Kim, W.K. (2013). Supplementation of direct-fed microbials as an alternative to antibiotic on growth performance, immune response, cecal microbial population, and ileal morphology of broiler chickens. Poultry Science, 92(8), 2084-2090. DOI: 10.3382/ps.2012-02947

Singh, H., Sodhi, S., Kaur, R. (2006). Effects of dietary supplements of selenium, vitamin E or combinations of the two on antibody responses of broilers. British Poultry Science, 47, 714-719. DOI: $10.1080 / 00071660601040079$

Sivaraman, G.K., Kumar, S., Saxena, V.K., Singh, N.S., Shivakumar, B.M. (2005). Genetics of immunocompetent traits in a synthetic broiler dam line. British Poultry Science, 46, 169-174.

Ślebodziński, A., Brzezińska-Ślebodzińska, E., Lipczak, W., Rosa, E. (1982). Simple clinical test for quantitation of the immunoglobulin complex and total serum proteins in neonates of the farm animals. Medycyna Weterynaryjna, 34, 442-446.

Sosnówka-Czajka, E., Herbut, E. (2001). Effect of short-term thermal stress early in rearing on performance and physiological indicators of broiler chickens. Annals of Animal Science, 1(2), 187-197.

Świerczewska, E., Niemiec, J., Noworyta-Głowacka, J. (2003). A note on the effect of immunostimulation of laying hens on the lysosyme activity in egg white. Animal Science Paper and Reports, 21(1), 63-68.

Truchliński, J., Krauze, M., Cendrowska-Pinkosz, M., Modzelewska-Banachiewicz, B. (2006a). Influence of garlic, synthetic 1,2,4-triasole derivative and herbal preparation Echinovit $\mathrm{C}$ on selected indices of turkey-hens non-specific immunity. Polish Journal of Veterinary Science, 9(1), 51-55.

Wang, Y.W., Field, C.J., Sim, J.S. (2000). Dietary polyunsaturated fatty acids alter lymphocyte subset proportion and proliferation, serum immunoglobulin $\mathrm{G}$ concentration, and immune tissue development in chicks. Poultry Science, 79, 1741-1748. DOI: 10.1093/ps/79.12.1741

West, A.P., Jr, Herr A.B., Bjorkman, P.J. (2004). The chicken yolk sac IgY receptor, a functional equivalent of the mammalian MHC-related Fc receptor, is a phospholipase A2 receptor homolog. Immunity, 20: 601-610. 
Yamada, K., Hung, P., Park, T.K., Park, P.J., Lim, B.O. (2011). A comparison of the immunostimulatory effects of the medicinal herbs Echinacea, Ashwagandha and Brahmi. Journal of Ethnopharmacology, 137(1), 231-235. DOI: 10.1016/j.jep.2011.05.017.

Yunis, R., Ben-David, A., Heller, E.D., Cahaner, A. (2000). Immunocompetence and viability under commercial conditions of broiler groups differing in growth rate and in antibody response to Escherichia coli vaccine. Poultry Science, 79, 810-816.

Yurong, Y., Ruiping, S., Shimin, Z., Yibao, J. (2005). Effect of probiotics on intestinal mucosal immunity and ultrastructure of cecal tonsils of chickens. Archives of Animal Nutrition, 59(4), 237-246.

Abstract

The aim of the study was to determine the effect of dietary addition of dried purple coneflower (Echinacea purpurea (L.) Moench) on selected blood parameters of chicks and hens of the native 'Greenleg Partridge' breed (Z-11), maintained on a certified poultry farm according to organic farming principles. Birds were divided into two groups according to diet: organic layer diet (group 1), and the same diet supplemented with certified purple coneflower from 20 weeks of age at $10 \mathrm{~g} / \mathrm{kg}$ feed (group 2). Layers were fed the certified layer diet (17\% protein and $11.1 \mathrm{MJ} \mathrm{ME} / \mathrm{kg}$ diet) following organic farming principles. Experimental incubations were performed at 34 weeks of age. Blood was collected from laying hens at 34 weeks and from newly hatched chicks at one day of age to determine selected blood parameters. The organically raised 'Greenleg Partridge' hens and chicks responded to the purple coneflower supplement by changes in their blood picture, which are important indicators of avian health and condition. As in Z-11 chicks, purple coneflower supplemented to the layer diet reduced the H:L ratio and induced a tendency for a higher level of the circulating immunoglobulin complex and IgG in blood, which shows their better living comfort and higher immunity. Dietary purple coneflower was observed to have no effect on the level of haematocrit, erythrocytes, and leukocytes. High individual variation occurred for the circulating immunoglobulin complex and IgG in the organically raised 'Greenleg Partridge' hens.

Key words: blood parameters, chicks, hens, immunity, organic production, purple coneflower

Received: [2018.07.12]

Accepted: [2018.12.20]

\section{Kształtowanie się wybranych parametrów krwi kur utrzymywanych zgodnie z założeniami rolnictwa ekologicznego i żywionych paszą z dodatkiem jeżówki purpurowej \\ Streszczenie}

Celem badań była ocena wpływu dodatku do paszy suszonej jeżówki purpurowej (Echinacea purpurea (L.) Moench) na kształtowanie się wybranych parametrów krwi piskląt oraz kur rasy rodzimej 'Zielononóżka Kuropatwiana' (Z-11) utrzymywanych zgodnie z założeniami rolnictwa ekologicznego na certyfikowanej fermie drobiu. Ptaki przydzielono do dwóch grup zróżnicowanych pod względem diety: nioski żywiono ekologiczną mieszanką paszową dla kur nieśnych (grupa 1), a w grupie 2 zastosowano od 20 tygodnia życia dodatek do paszy certyfikowanej jeżówki purpurowej w ilości $10 \mathrm{~g} / \mathrm{kg}$ paszy. Nioski żywiono certyfikowaną mieszanką paszową dla kur nieśnych zgodnie z założeniami rolnictwa ekologicznego o zawartości białka 17\% i energii metabolicznej wynoszącej 11,1 MJ/kg paszy. W 34 tygodniu odchowu przeprowadzono lęgi doświadczalne. Również w 34 tygodniu odchowu pobrano krew od kur nieśnych oraz w pierwszym dniu życia nowowyklutych piskląt w celu oznaczenia wybranych parametrów krwi. Reakcją na podanie jeżówki purpurowej były zmiany w obrazie krwi kur oraz piskląt rasy 'Zielononóżka Kuropatwiana', utrzymywanych zgodnie z założeniami rolnictwa ekologicznego, będące ważnymi wskaźnikami zdrowotności i kondycji zwierząt. Dodatek do paszy dla kur nieśnych jeżówki purpurowej wpłynął podobnie jak w przypadku piskląt Z-11 na zawężenie stosunku H:L, a także na wystąpienie tendencji do wyższego poziomu kompleksu immunoglobulinowego oraz IgG we krwi, co wskazuje na ich lepszy komfort bytowy i większą odporność. 
Nie wykazano natomiast wpływu jeżówki purpurowej w paszy na kształtowanie się poziomu hematokrytu, erytrocytów oraz leukocytów. Stwierdzono występowanie bardzo dużej zmienności osobniczej w przypadku kompleksu immunoglobulinowego oraz IgG u kur rasy 'Zielononóżka Kuropatwiana' w chowie ekologicznym.

Słowa kluczowe: parametry krwi, pisklęta, kury, odporność, produkcja ekologiczna, jeżówka purpurowa

Information on the authors

Ewa Sosnówka-Czajka https://orcid.org/0000-0003-3720-1685

She is an assistant professor at the Department of Poultry Breeding in the National Research Institute of Animal Production in Cracow. She is interested mainly in poultry welfare and the technology of poultry production.

Iwona Skomorucha https://orcid.org/0000-0003-1241-7703

She is an assistant professor at the Department of Poultry Breeding in the National Research Institute of Animal Production in Cracow. She focuses also on poultry welfare and the technology of poultry production. 


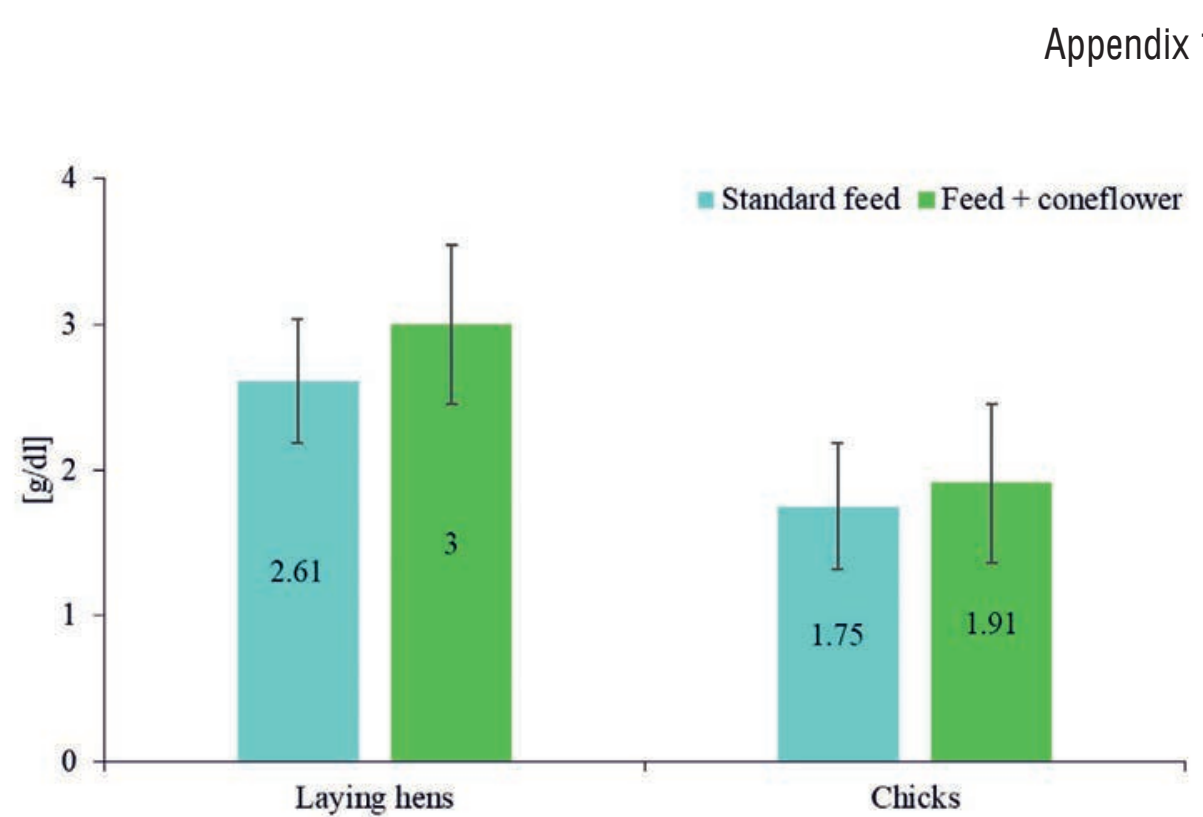

Fig. 1. The level of the circulating immunoglobulin complex [g/dl]; the error bars denote the standard deviation $( \pm S D)$ of the mean value; $\mathrm{n}=15$

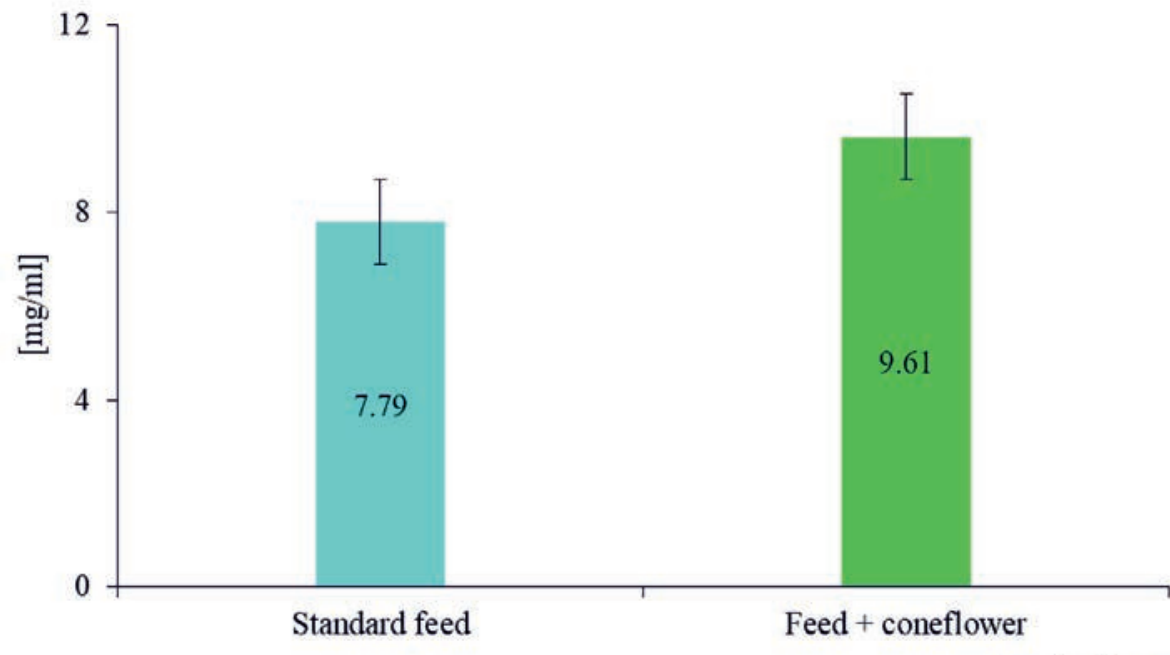

Laying hens

Fig. 2. The level of $\operatorname{IgG}[\mathrm{mg} / \mathrm{ml}]$; the error bars denote the standard deviation $( \pm \mathrm{SD})$ of the mean value; $\mathrm{n}=15$ 


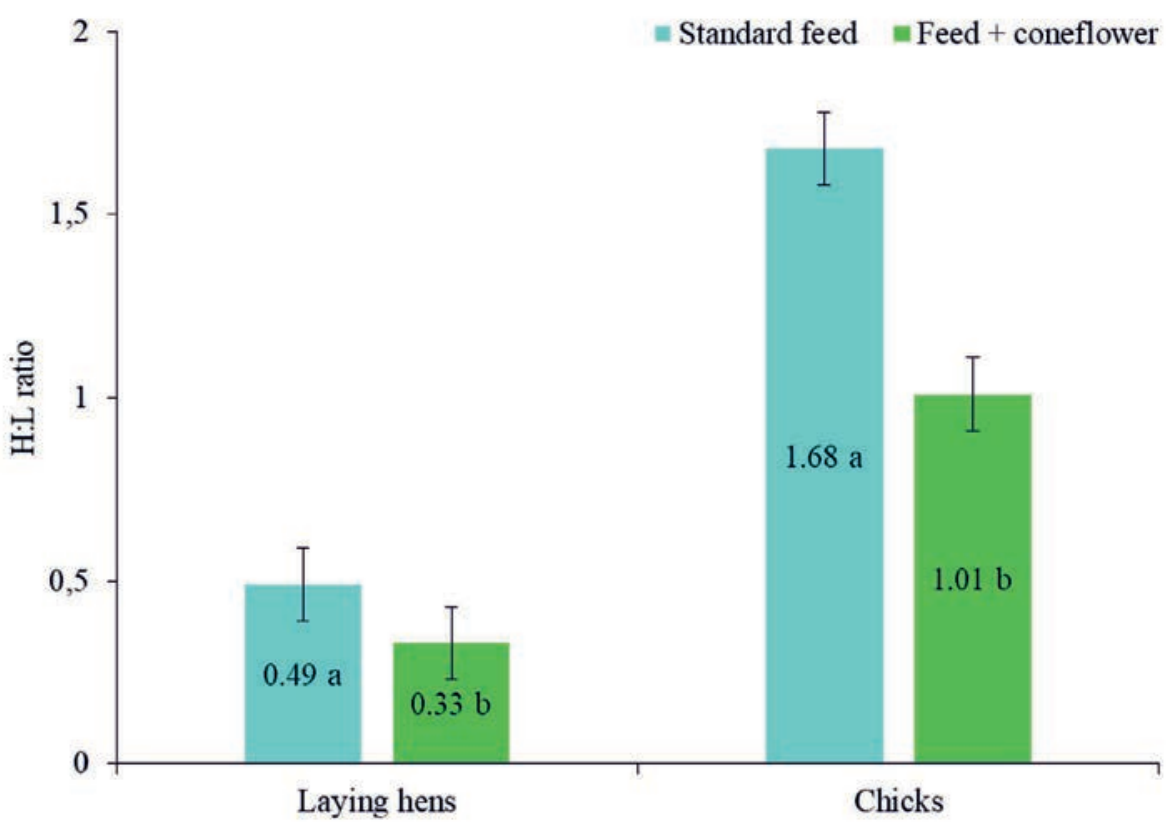

Fig. 3. Heterophil to lymphocyte ratio - H:L; significant differences between the treatments in groups in hens and chicks are indicated with different letters $(\mathrm{a}, \mathrm{b}-\mathrm{p}<0.05$, Duncan test); the error bars denote the standard deviation $( \pm S D)$ of the mean value; $\mathrm{n}=15$

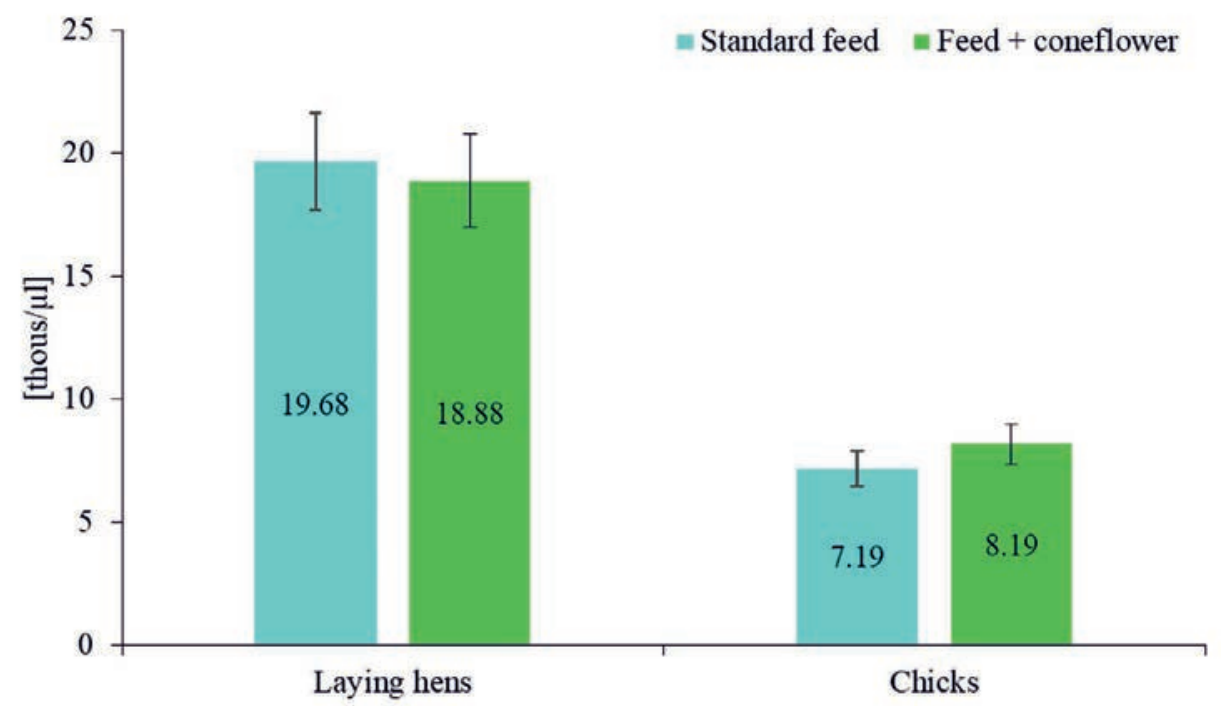

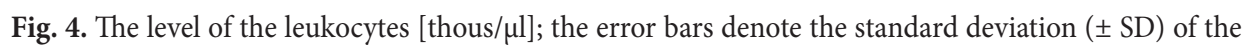
mean value; $\mathrm{n}=15$ 


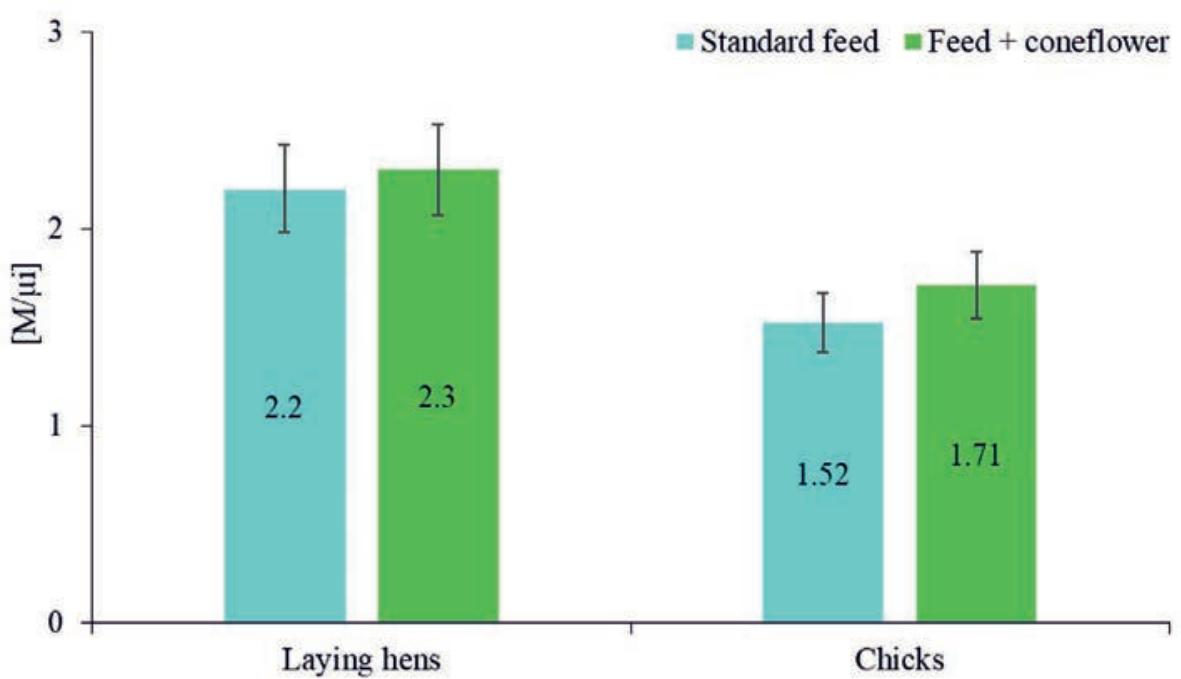

Fig. 5. The level of the erythrocytes $[M / \mu l]$; the error bars denote the standard deviation $( \pm S D)$ of the mean value; $\mathrm{n}=15$

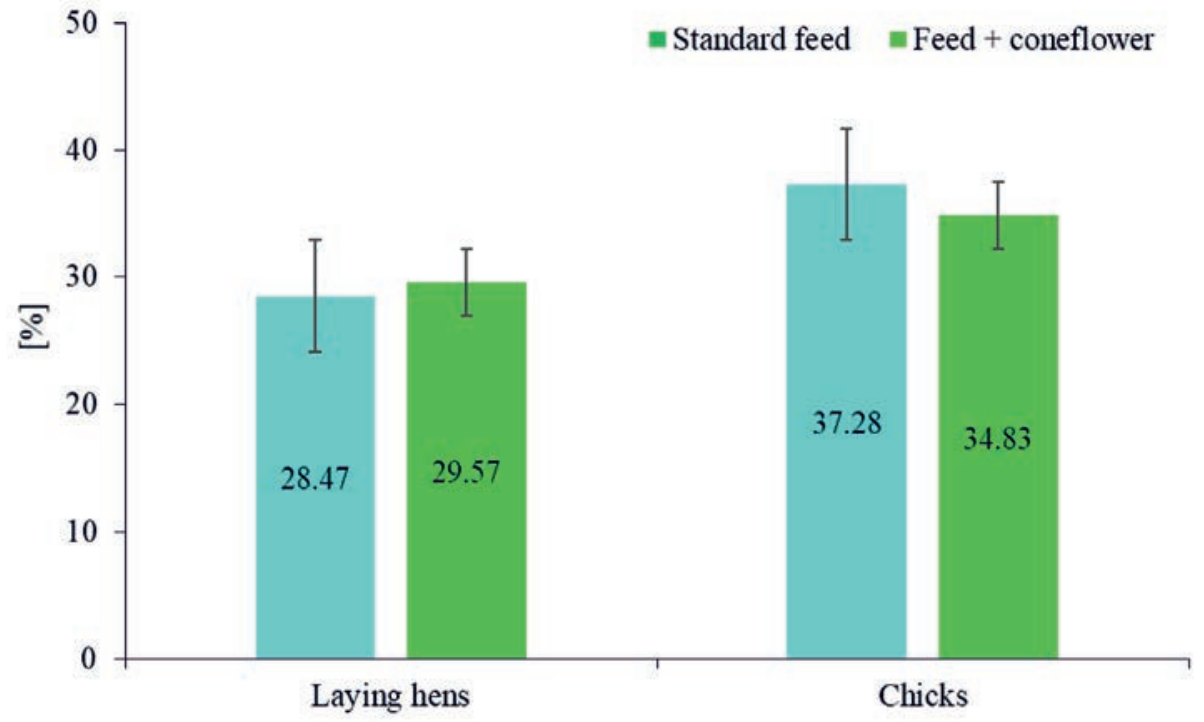

Fig. 6. The level of the haemoglobin [\%]; the error bars denote the standard deviation ( \pm SD) of the mean value; $\mathrm{n}=15$ 